\title{
ADDRESSING THE NEEDS OF LAWYERS IN LEGAL ENGLISH: A COMPARATIVE STUDY IN FOUR EUROPEAN UNION COUNTRIES
}

\author{
Halina SIEROCKA \\ Białystok Legal English Centre, Faculty of Law \\ University of Białystok, Poland \\ soll@poczta.onet.pl \\ Barbora CHOVANCOVÁ \\ Language Centre, Faculty of Law \\ Masaryk University, Brno, Czech Republic \\ barbora.chovancova@law.muni.cz \\ Ljubica KORDIĆ \\ Foreign Languages Centre, Faculty of Law \\ Josip Juraj Strossmayer University of Osijek, Croatia \\ kljubica@pravos.hr
}

\begin{abstract}
The paper reports on a survey into the linguistic needs of law professionals in four European countries, with the aim of identifying their views on the importance and their use of foreign language skills as well
\end{abstract}


as their preferences for ELP course content. The data, obtained from a questionnaire survey of 536 legal professionals from Poland, the Czech Republic, Croatia and Germany, show that while the respondents agree on many of the major points, there are also some differences conditioned by the respondents' age and the specific tasks they perform in the legal profession. The article argues that these variables have to be taken into consideration in the LSP context because they determine some of the specific needs that need to be addressed in Legal English instruction. It is suggested that the findings about the lawyers' self-perceived importance and preferred styles of learning are highly relevant for LSP practitioners, particularly when designing Legal English programmes and testing materials.

Keywords: needs analysis, English for Legal Purposes (ELP), Legal English, English for Specific Purposes (ESP)

\section{FORMULOWANIE POTRZEB PRAWNIKÓW W ZAKRESIE JĘZYKA ANGIELSKIEGO PRAWNICZEGO: STUDIUM PORÓWNAWCZE CZTERECH KRAJÓW EUROPEJSKICH}

Streszczenie: Artykuł stanowi badanie potrzeb lingwistycznych osób wykonujących zawody prawnicze w krajach europejskich, w celu określenia ich poglądów co do ważności i użytkowania przez nich języków obcych oraz pod kątem treści kursów prawniczego języka angielskiego. Analizowane $\mathrm{W}$ artykule dane pochodzą $\mathrm{z}$ ankiety wypełnionej przez 536 prawników w Polsce, Czechach, Chorwacji i Niemczech. Wskazują one, że respondenci są zgodni w zakresie głównych kwestii, jednakoż istnieją wśród nich pewne różnice poglądowe, które zależą od ich wieku oraz określonych aktywności realizowanych $\mathrm{w}$ danym zawodzie prawniczym. $\mathrm{W}$ artykule podjęto polemikę nad faktem, iż takie różnice winny być uwzględnione w zakresie nauczania języków specjalistycznych, ponieważ identyfikują określone potrzeby i z tego względu należy je brać pod uwagę w nauczaniu prawniczego języka angielskiego. Autorki sugerują, że wskazania indywidualnej oceny roli języków obcych i preferowanego stylu uczenia się powinny być aplikowane podczas opracowywania programów nauczania i oceny języka specjalistycznego, a szczególnie języka prawniczego angielskiego, kierowanego do prawników.

Stowa kluczowe: analiza potrzeb, prawniczy język angielski (ELP), prawniczy angielski, specjalistyczny język angielski (ESP) 


\section{Introduction}

In conditions of globalization and business and political associations worldwide, lawyers are faced with new challenges, primarily those including the necessity to communicate with other legal professionals. As English has become the lingua franca of international communication, the globalization and internationalization processes inevitably influenced lawyers' needs within Legal English as a vehicle of communication in their profession. In that context, this paper focuses on determining the needs and preferences of lawyers in four European countries: Germany, Croatia, Poland and the Czech Republic in Legal English by using needs analysis methodology.

According to the Oxford dictionary ${ }^{1}$, needs analysis is defined as the systematic analysis of the particular needs of an individual or institution that is mostly applied in education or management. In educational contexts, needs analysis is understood as a systematic collection and analysis of the target situation needs, its aim being to point at a desired final destination of the course and syllabus design (Hutchinson and Waters 1987: 54). Needs analysis is generally perceived as the foundation for the development of LSP (Languages for Specific Purposes) programs (Swales 1990; Robinson 1991; West 1994; Jordan 1997; Dudley-Evans and St John 1998; Deutch 2003; Jeong 2005; Cowling 2007; Songhori 2008; Kassim 2010; Wozniak 2010; Akbari 2011; Tsao 2011; Lockwood 2012). Although there are some scholars (Benesch 1996; Spratt 1999; Basturkmen 2006) who present a critical approach to needs analysis, questioning its objectivity and reliability and the fact that it may serve the interests of the institutions at the expenses of learners or that the perceptions of needs differ and are frequently contradictory, the value of needs analysis cannot be underestimated. As many academics (Bacha \& Bahous 2008; Songhori 2008; Sierocka 2014; Chovancová 2014) highlight, a needs analysis contributes to a great extent not only to effective LSP syllabus design and course development but also to its implementation and assessment. By participating in needs analysis, the target group of students

\footnotetext{
${ }^{1}$ https://en.oxforddictionaries.com, 13.9. 2017 at 22:53
} 
(course attendants) is encouraged to take active roles in determining goals and particular contents of their own learning, an approach which Hyland describes as "negotiated syllabus" (2009: 208). There are numerous sources that may be of use to collect the data for needs analysis. They encompass the present and former students, people working and / or studying in the domain, employers, clients, colleagues or other researchers (Chovancová 2013). The most popular means and techniques of data collection are outlined by Jordan (1997: 30-39) and include, for example, surveys and questionnaires, language tests, structured interviews, case studies or evaluation / feedback forms. The research presented in this paper is founded on the needs analysis carried out in four European countries on a large sample of respondents.

\section{Purpose and context of the research}

As indicated in the introduction to this paper, being able to communicate effectively with other people in the legal profession is of paramount importance and particularly so when working in an international environment. Thus, there is the continuous need for the university to produce law graduates who are best equipped with knowledge, skills and competences that are most valuable for the prospective profession, making English for Legal Purposes (ELP) instruction attractive and motivating as well. Consequently, perceptions of legal professionals in that respect, who, in any case, are some of the stakeholders in the process should be taken into consideration while planning the curriculum and developing and/or testing materials.

The aim of the research project was to identify the perceptions of European legal professionals on the importance of particular linguistic skills (i.e. reading, writing, speaking and listening) or areas of language use and the methodology implemented (i.e. learning strategies or aids) as well as preferences for ELP course content. The research was conducted in four European countries (Croatia, the Czech Republic, Germany and Poland) in 2014 and 2016, when Legal English teachers from 
these four countries worked together on planning and developing an Erasmus+ project initiated by the Faculty of Law of the University of Bialystok (Poland). Although the countries participating in the research differ in their population number and historical legal development, they are connected by similar legal traditions founded in continental civil law system and by the fact that significant changes have been introduced in their respective legal systems following accession to the European Union. In that context, the findings of this research can be a relevant contribution in the sphere of LSP theory and practice. Although the results of the research cannot be taken as representative of Europe as a whole, they do serve as a relevant and reliable basis in curriculum development and designing teaching and testing materials in Legal English in the four countries featured. The questionnaire used for gathering data was administered offline and online. Accordingly, due to the methodology applied, we were not able to target respondents of the same age, so discrepancies regarding the number of respondents and their age occurred between the four countries. The authors are of the opinion that the differences in number of respondents do not disturb the statistical significance of the sample, if we take into account the fact that the population number differs significantly between the four countries, especially between Poland and Croatia - the two countries with the greatest difference in sample. Whether the respondents' age represents a significant variable of the research will be established by comparing the results in the German sample with those of the other three countries since, on average, German respondents tended to be older than those in Croatia, Poland and the Czech Republic. 


\section{Research methodology}

\subsection{Sample}

The sample for the study comprised 536 legal professionals who were the target group for this research. For the purposes of the research, it is assumed that a legal professional is an adult professional involved with legal English as a factor of his/her work, i.e. graduate lawyers employed in law firms, prosecution, public administration, the judiciary and other branches of the legal profession. The Croatian sample consisted of 62 legal professionals comprising 27 attorneys, 6 judges and court staff, 8 clerks, 5 legal advisors, 9 interns and 7 other legal professionals (mainly academic staff). The German sample group encompassed 80 legal professionals including 12 judges, 65 attorneys and solicitors and 3 prosecutors. The sample group from the Czech Republic, the most varied of the four countries, consisted of 103 legal professionals comprising 22 attorneys, 21 legal advisors or solicitors, 11 interns, 9 professionals involved in teaching or research, 9 civil servants, 6 in-house lawyers, 3 bailiffs, 2 students, 2 paralegals, 2 mediators and 2 law graduates who at the time of survey were currently on maternity leave. The rest of the sample included respondents who believed they do not belong to any of the above-listed categories and described themselves e.g. as a businessman, a financial auditor, a head of strategic procurement, a legal specialist in clinical trials or unemployed. The Polish sample comprised 291 legal professionals including 48 attorneys, 68 legal advisors, 74 judges and court staff, 25 notaries and 76 civil servants. The age ranged from newly-qualified lawyers of 23 years of age to those who were over 65 . The respondents were not asked to declare their perceived language proficiency as without reliable testing, this information would have little if any validity. They were, however, presumed to have at least a working knowledge of English. Structural diversity of the four samples is caused by the methodology used and the time in which the data were collected in each country. This represents one of the limitations of the research in that 
the results obtained might not be easily generalizable. However, they are comparable and can be indicative for European countries of a similar legal and political background.

\subsection{Research instruments and research questions}

The research project assumed a qualitative and quantitative methodology encompassing a questionnaire (hereto appended), which was administered locally by the authors in their own teaching environment either offline (paper version distributed during Legal English courses) or online in such manner that enabled the authors to first canvass and then maintain contact with local lawyers available online, as well as e-mail contacts available at the respective local higher education institution that the authors of the paper are employed in. Due to the online methodology used for collecting the data, it was not possible to influence how many respondents we shall have from different professional fields.

The research questions referred to the following aspects:

- $\quad$ general objectives legal professionals wish to achieve from a Legal English course,

- the skills considered most useful to them in their respective domains,

- the course content (the coverage of particular legal domains and the role of grammar and vocabulary),

- teaching and learning strategies and methods which are most efficient while learning Legal English,

- the reasons for their learning Legal English.

Specific questions included in the questionnaire were as follows:

- What would legal professionals like to achieve during the Legal English course? 
- Which specific objectives within the four skills (listening, reading, speaking and writing) are the most important to them?

- Which particular discipline of law is the most useful for legal professionals?

- What is the role of grammar in such a course?

- Which skill/skills is/are the most helpful for them while learning a foreign language?

- What is the most important element of Legal English learning?

- What aid/aids is/are the most helpful in the process of foreign language (including Legal English) learning?

- What do legal professionals need Legal English for?

The data indispensable to answering the questions are both quantitative and qualitative in character and were collected by means of the needs analysis questionnaire completed by all respondents. The questionnaire was administrated offline (by distributing paper copies of the questionnaire) and online. As before mentioned due to the online methodology used for collecting the data, it was not possible to influence the number of respondents we could attract from different fields of the legal profession and likewise we were unable to target respondents of the same age, so inconsistencies regarding the number of respondents and their age are apparent between the four countries. The authors are of the opinion that the differences in number of respondents do not decrease the statistical significance of the sample, if we take into account the fact that the population number differs enormously between the four countries, especially between Poland and Croatia - the two countries with the widest difference in sample. Whether the respondents' age represents a significant variable of the research may be established by comparing the results in the German sample with those of the other three countries, as on average the German respondents were generally older than those in Croatia, Poland and the Czech Republic.

In the main part of the paper, the data gathered are interpreted, compared and analysed with respect to similarities and differences in the opinions of the respondents from each 
of the four countries. In the analysis the Chi-square test is used to establish significant statistical difference between the answers of the respondents from the four countries. Finally, the results are discussed with specific reference to limitations of the research and conclusions drawn.

\section{Results of the study}

\subsection{Croatia}

\subsubsection{General objectives}

Croatian respondents comprised 62 legal professionals of younger generation, most of them being between 23 and 34 years age. They assessed developing the skills necessary to communicate with other people within their profession as the most important objective of a Legal English course (68\%). Being able to establish and maintain relationships through the exchange of information was ranked as second (61\%). Other general objectives of Legal English teaching do not seem to be very important to Croatian lawyers (selected by $20 \%$ of respondents and less).

\subsubsection{Most useful skills}

All language skills are seen as important by Croatian respondents. However, the speaking skill is highlighted as the most important by most (85\%), followed by writing (56\%), reading (47\%) and listening $(44 \%)$. When talking of specific objectives within each of these skills, we can say that Croatian respondents are very decisive and confident in their choice, as specific objectives were in most cases selected by an overwhelming majority of them. Thus, for example, in the field of writing, almost all respondents (94\%) 
selected formal correspondence as the crucial specific objective. Drafting pleadings and statements of cases was assessed as an important objective by $52 \%$ of respondents, while writing reports, proceedings, notices, memos, etc. was third in rank, chosen by $48 \%$. As for the specific objectives in the field of speaking, the respondents were confident that public speaking (giving lectures, presentations, public speeches, etc.) was the most useful skill to master (selected by $73 \%$ of the respondents). Abilities to negotiate and to express agreement or disagreement were assessed as second in rank, being chosen by 63 $\%$ of the respondents. In the field of listening, listening for detail was underlined as the most important and most useful skill by the majority of respondents $(85 \%)$. Listening to public statements was ranked second, chosen as crucial by $63 \%$ of the respondents, followed by understanding telephone conversation $(55 \%)$. In terms of reading, Croatian respondents were decisive that understanding authentic materials (both in reading for gist and for detail) represented the most desired objective (92\%). Accordingly, improving and revising vocabulary based on authentic materials was also assessed as both important and useful $(76 \%$ of respondents), while searching for and understanding particular information was third in rank, chosen by $52 \%$ of respondents.

\subsubsection{Course content}

The course content in a wider sense in the light of needs analysis comprises teaching foreign language (grammar, vocabulary and pronunciation) through specific content areas - here the field of law. Mastering grammatical knowledge is an important element in (professional) communication in a foreign language. Most of the Croatian respondents (58\%) expressed the opinion that only essential grammatical structures should be revised in a Legal English course, whereas 39\% thought grammar should be revised thoroughly. Interestingly, 94\% considered teaching vocabulary as a crucial element of a Legal English course. As for specific domains in which legal terminology and phraseology should 
be acquired, they gave priority to civil law (73\%) and European law (58\%). Third position was shared equally by commercial law and contract law (50\% each). Other preferences were obviously influenced by the respondents' specific field of work, as other legal disciplines were selected by less than $20 \%$ of the respondents.

\subsubsection{Teaching and learning strategies and methods}

As stated previously, the Croatian sample group selected speaking and then writing as crucial linguistic skills. These skills should be developed by using different methods and linguistic tools focused on acquiring legal vocabulary (claimed by as much as $94 \%$ of the respondents) within specific (preferred) disciplines of law. When speaking about strategies and methods that might be helpful in achieving that goal, most Croatian respondents (85\%) highlighted working with a native speaker as most helpful, and, similarly, working as a lawyer in foreign language environment was classified second in rank (68\%). The answers referring to written or audio-visual media as aids in teaching/learning Legal English were chosen by less than $20 \%$ of respondents in each case.

\subsubsection{Reasons for learning Legal English}

Most of the Croatian respondents expressed the opinion thatmastering Legal English is necessary to improve their skills and qualifications $(76 \%)$ and thus necessary in their work $(60 \%)$. Accordingly, $48 \%$ of the respondents were confident that it would raise their (or their firms') value and give them advantage on the labour market. 


\subsection{Czech Republic}

\subsubsection{General objectives}

With more than $90 \%$ of the respondents being in the 23-34 age category, the results of the questionnaire show primarily the needs of professionals in the early stages of their careers. $62 \%$ of respondents believed that Legal English is necessary to improve their skills and qualifications, closely followed by the simple fact that English is needed in their job (61\%). When stating their general aim, almost $70 \%$ of respondents said they would like to develop skills necessary to communicate with people in their profession, while $40 \%$ strive to improve their letter writing skills.

\subsubsection{Most useful skills}

The four basic language skills (reading, writing, speaking and listening) were analysed in depth with the following results. An overwhelming majority of respondents (92\%) selected formal correspondence as the most important type of writing task to improve. Other skills chosen as crucial for their profession included drafting of reports, proceedings, notices, memos (68\%), very closely followed by drafting pleadings and statements of cases $(67 \%)$. The top three speaking skill categories cover negotiating (81\%), public speaking e.g. giving lectures, presentations and public speeches (66\%), and holding telephone conversations in English (55\%). As far as listening skills are concerned, Czech lawyers stated that they feel they need practice especially while listening for detail (72\%) and understanding telephone conversation $(71 \%)$, with some of them commenting on the fact that listening is not only about hearing the correct words but also about understanding underlying issues such as the nature of specific legal problems, judicial procedure or discussions on legal topics. As far as reading skills are concerned, 
the overwhelming majority, not surprisingly, selected understanding authentic materials as the most relevant (94\%), followed by searching for and understanding particular information (73\%) and improving and revising vocabulary on the basis of authentic materials (62\%).

\subsubsection{Course content}

For Czech lawyers, the most important discipline of law to be conversant with in English is that of contract law, with $68 \%$ of respondents listing it as one of their four priorities. Maybe somewhat surprisingly the state-specific civil law (family law, property law, intellectual property law, inheritance law) and the internationally focused commercial law gained similar popularity on the list of preferences, the former $59 \%$ and the latter $58 \%$. As to be expected with such a multifaceted discipline as law, the respondents also listed their individual preferences namely the disciplines of law in which they specialize, e.g. IT law, procedural or environmental law and EU competition law.

\subsubsection{Teaching and learning strategies and methods}

Czech lawyers believe that all four skills are important, rating reading, writing and listening almost at par (37\%, $40 \%$ and $42 \%$ respectively), but are unequivocally in favour of the importance of skill in speaking (77\%). Similarly, prominent, is their preference of acquiring professional vocabulary as the cornerstone of Legal English training (87\%), with one of the respondents hastening to clarify that it is "not only vocabulary but primarily (sic.) understanding the words in its legal system". Other areas of Legal English learning were seen as being of significantly less importance. When listing what may help in the acquisition of a foreign language, Czech respondents believe in the benefit of working with a native speaker $(68 \%)$, as well as working in a foreign language environment (55\%). The media 
(TV, radio and Internet) was considered the third most important language-learning tool (34\%).

\subsubsection{Reasons for learning Legal English}

More than half of the respondents (54\%) stated that mastery of Legal English is necessary in their work, while $18 \%$ felt they did not need this skill when performing their day-to-day activities. More than one third of lawyers (39\%) believed that professional language skills in English would raise their value and give them an advantage on the labour market.

\subsection{Germany}

\subsubsection{General objectives}

German respondents comprised mostly judges and attorneys, including legal advisors. As 50\% of them were over the age of 51 (40\% being between 35 and 50), we can say that their opinions are based on their long working experience and can be taken as highly relevant and indicative for all legal professionals. Developing the skills necessary to communicate with other people was assessed as the most important objective of a Legal English course by the vast majority of respondents (80\%). One third believed that a Legal English course should also include elements of general language, which is confirmed by their opinion that it would prepare attendants to participate in conversation related to everyday situations (35\%), and assist them in engaging in free conversation (30\%). 


\subsubsection{Most useful skills}

When deciding on the importance of the four language skills for legal professionals, the respondents ranked speaking (70\%) and listening $(60 \%)$ as the most important skills. Writing was considered rather important (40\%), which could not be claimed for reading $(25 \%)$.

A majority of respondents perceived formal correspondence and writing pleadings or statements in a case as the most useful objectives in the field of writing (each answer selected by $75 \%$ of respondents). Writing application letters, CVs, invitations etc. was assessed as crucial by $35 \%$ of respondents, and exactly the same percentage assessed writing reports, proceedings, notices, memos, etc. as being of equal importance. The third place according to the significance was shared between informal correspondence and writing application forms, questionnaires etc., each of the two answers being selected by $30 \%$ of the respondents.

Speaking skills, as we have seen, are highly appreciated communication skills within Legal English by most of all the respondents. The most important specific objective within these skills, according to German respondents, is speaking to the public (giving lectures, presentations, public speeches) this answer was chosen by $70 \%$ of the respondents. A slightly lower percentage thought that negotiating $(65 \%)$ and problem solving (60\%) represented the most central objectives within speaking skills. Giving opinions, especially expressing agreement and disagreement, is not less important for lawyers, which was confirmed by $50 \%$ of the respondents. The answers by German respondents were more dispersed as far as specific objectives in the field of listening are concerned, majority thought that listening for details should be developed due to its significance $(65 \%)$, followed by listening to public statements (e.g. information, instructions and warnings) represented by $60 \%$ of the respondents. Half of the German group thought that understanding telephone conversation in English was vital for German lawyers in performing their profession, whereas $40 \%$ said that obtaining necessary information in different situations (at the hotel, railway 
station) was also an important objective in this area. $35 \%$ found understanding of TV or radio news crucial as well.

The answers by German respondents were more unified concerning specific objectives in the field of reading. The first rank is shared between understanding authentic reading materials and searching for (and understanding) particular information within the text, each answer being chosen by $65 \%$ of the respondents. Ability to follow specific information while reading was ranked second (50\%), followed by the ability to improve and to revise vocabulary based on authentic materials (40\% each).

\subsubsection{Course content}

The elements of the course content questioned in this research referred to three areas of ELP teaching ELP: grammar, vocabulary, pronunciation as three crucial linguistic elements in language teaching as well as the role of grammar in teaching a foreign language, and the subject area (the most preferred disciplines of law). As for the three crucial linguistic elements of a Legal English course, most respondents were of the opinion that special attention should be paid to teaching vocabulary (55\%), while teaching grammar and pronunciation were respectively assessed as important by only $25 \%$ and $20 \%$ of respondents. Notwithstanding, most respondents found that grammar should be revised thoroughly (59\%), whereas $38 \%$ said that only essential structures should be discussed. When choosing the discipline law that a Legal English course should be focused on, opinions naturally varied depending on the respondent's specific field of interest. However, four legal domains can be highlighted as most important for German lawyers: European law (70\%), commercial law $(60 \%)$, financial law and criminal law (each 50\%). Civil law was preferred by (40\%) of respondents and contract law by $35 \%$. 


\subsubsection{Teaching and learning strategies and methods}

As already indicated in 4.3.2 above, German respondents primarily favour speaking skills, followed by listening and writing skills. Accordingly, professional vocabulary within chosen legal domains should be the focus of Legal English discourse. In determining which aids, methods and strategies may be helpful in acquisition of a foreign language for specific purposes, the overwhelming majority of German lawyers unequivocally claimed that the most helpful aid is working with a native speaker (80\%), but also the media (TV, radio, the Internet) can be supportive (45\%) as well as books, newspapers and magazines (35\%). Interestingly, working as a lawyer in a foreign language environment was not selected at all, probably on the grounds that this answer was seen as closely connected with that of working with a native speaker.

\subsubsection{Reasons for learning Legal English}

The German respondents laid stress on the importance of mastering Legal English for their professional career. The option that it would raise their (or their firm's) value and give them advantage on the labour market was chosen by $85 \%$ of the group. Consistent therewith, 65\% agreed that Legal English was necessary in their work, while 55\% expressed the opinion that it would improve their skills and qualifications. 
Halina SIEROCKA et al.: Addressing the Needs...

\subsection{Poland}

\subsubsection{General objectives}

Developing the necessary skills to communicate with other people in their field of work was selected as the primary aim of the course by $68 \%$ of the Polish group. In second place, they chose the ability to establish and maintain relationships through the exchange of information (40\%). Maintaining correspondence was thought to be important by $30 \%$ of the respondents.

\subsubsection{The most useful skills}

One of the tasks of our needs analysis was to discover which specific objectives within each of the four skills are preferred and perceived by lawyers as necessary in their profession. The outcomes of the needs analysis quite clearly indicate that formal correspondence is the most central element in learning how to write in Legal English (83\%). Furthermore, the Polish legal professionals selected writing pleadings and statements of cases as their second choice (55\%). Learning how to prepare application forms and questionnaires and how to write reports, proceedings, notices and memos in English both merited third place in terms of significance (each being selected by $36 \%$ of the respondents).

Interestingly, it can be stated that giving opinions (62\%) and holding telephone conversations (61\%) were considered similarly important as far as speaking is concerned. Negotiating came a close second (50\%) and public speaking (i.e. giving lectures and public speeches) as their next choice (45\%). In terms of listening, the Polish legal professionals seem to be quite decisive in their choices as $75 \%$ selected understanding telephone conversations as the most crucial listening skill, which was followed by listening for detail $(58 \%)$ or listening to public statements (e.g. information, instructions and warnings etc.), which was a close choice as well (57\%). The Polish research group 
was confident in expressing exactly what they in fact need in the field of reading. Understanding authentic materials is undoubtedly a high priority for the respondents (82\%). Searching for and understanding specific information was ranked second (64\%) and improving and revising vocabulary using authentic materials came in third (62\%). Assessment of the importance of grammar in a Legal English course divided the Polish research group nearly equally into a group who believes that grammar should be revised thoroughly (47\%) and those who think that only the essentials are necessary (46\%), with the rest stating that grammar has no place in a specialist English course.

\subsubsection{Course content}

As it was mentioned before, three aspects of course content were examined. They comprised the coverage of particular legal domains and their share in the Legal English course, the role of grammar in the course and the most critical element of the course (selecting from grammar, vocabulary or pronunciation). As far as legal domains are concerned, no discipline commands a clear majority. The most practical were: European law (54\%), commercial law (51\%), contract law (51\%), civil law (42\%) and international law (40\%). Moreover, the respondents were quite positive that only essential grammatical structures should be discussed within the course for legal purposes (68\%), however, almost a third of the group (28\%) believed that grammar should be revised thoroughly during the course, whereas a minority of respondents (12\%) expressed the opinion that such a course should cover no grammar at all. Taking into consideration the most important element of an ELP course, a significant number of respondents $(86 \%)$ pointed to vocabulary. 


\subsubsection{Teaching and learning strategies and methods}

The analysed teaching and learning strategies and methods concerned the skills and aids which are most helpful while learning Legal English as well as the preferred ways of studying.

Based on the outcomes determined, it can be ascertained that speaking is perceived as the most useful skill by Polish legal professionals (85\%), followed by writing (56\%) and listening (49\%). Interestingly, the research revealed that reading is the least important, most probably due to the fact that there are numerous offline and online tools which help them to clarify the meaning of a written text. When asked what aid/aids (respondents could choose more than one aid) is/are most useful in the process of learning Legal English they showed great confidence in working with a native speaker $(62 \%)$ or working as a lawyer in foreign language environment (57\%). The third option was the media ( $\mathrm{TV}$, radio and the Internet $-44 \%$ ), most probably treated as good sources of authentic material.

\subsubsection{Reasons for learning Legal English}

Although the results received under this section of the study reveal that for the sizable majority $(67 \%)$ of the Polish legal professionals Legal English is not necessary in their work, the Polish research group agreed that it would definitely improve their skills or qualifications (71\%) and would raise their (or their law firm's) value and give an advantage on the labour market (81\%).

\section{Discussion}

The research into the language needs of practicing lawyers described above covered a sample of 536 lawyers from four European countries - Croatia, Germany, the Czech Republic and Poland. 
Although we can observe differences in the structures of the four respondents' bodies, the analysis of the results revealed many similarities in their opinions. The general impression is that respondents from the four countries share positive attitudes towards the usefulness of Legal English for legal profession and general objectives of modern Legal English course. They are almost unanimous in the opinion that it would raise their (or their law firm's) value, provide an advantage on the labour market, and improve their skills and qualifications. The most important outcome of the study, especially keeping in mind its didactic implications for teaching Legal English in EU member states, is the fact that a high number of practising lawyers said that Legal English was necessary in their work. This opinion was shared by $60 \%$ or more of Croatian, Czech and German lawyers $(60 \%, 61 \%$ and $65 \%$ respectively). This finding may come as a surprise, given the fact that law has always been seen as a localized profession. The only country in which fewer lawyers were reported using English in their everyday working life is Poland - only 33\% of Polish respondents needed the command of Legal English to perform their work well. The Chi-square test suggests that the extent in which Polish respondents use English language in their profession is significantly lower than in other three countries $(\mathrm{p}<0.05)$. Despite this fact, a great majority of Poles still believe that mastery of English would improve their career prospects and strengthen their firm's competitive position in the marketplace. The difference occurring in the answers by the Polish respondents may also be seen as a result of the makeup of the Polish contingent, in which $26 \%$ of respondents (76 out of 291) are civil servants, which is not the case in other three countries. If we compare the answers given by respondents performing in different fields of the legal professions, we can readily see that most civil servants $(53 \%)$ as well as notaries (60\%) in Poland expressed the opinion that mastering Legal English is not important in performing their work.

The Croatian, Czech and Polish sample comprised of the respondents at the beginning of their professional career, the German ones, on the other hand, were nearly all older than 35 . This fact is possibly reflected in their marked preference for communication in English in general and social contact 
in particular. Being at a higher level on the professional ladder, the German respondents probably spend more time representing their law firms than dealing with everyday routine tasks such as drafting documents or responding to e-mails as their younger counterparts do. This result implies that the age of respondents and their specific professional scope of activities (most respondents were judges and attorneys, including legal advisors) represent statistically significant variables determining the preferences and needs of legal professionals in Legal English.

When deciding on the importance of individual skills, speaking skills are, however, felt to be vital by all lawyers across the sample (Croatia 85\%, Czech Republic 77\%, Germany 70\%, and Poland 85\%), and in this respect no significant statistical difference was found ( $p>0.05$ ). Other skills were ranked as roughly equally important by the Czechs, the Poles and Croatians ascribing more importance to writing. Again, a different opinion was voiced by the German contingent who consider listening to be far more important than reading or writing. This again could be explained by their specific professional tasks as judges and attorneys, statistical difference being $(\mathrm{p}<0.05)$.

As far as writing is concerned, in a skill ranked as the second most important by the respondents from all four countries, formal correspondence was felt to be of first and foremost priority, with no significant statistical difference. Drafting statements and cases was placed second, with all the other categories (e.g. reports, notices, proceedings, memos, etc.) all featured on the "need to master" list.

It seems that lawyers in Croatia, the Czech Republic and Germany need to speak in public in their day-to-day work, whereas their Polish counterparts tend to need to express their opinions and hold telephone conversations and negotiate more than speak in front of a larger audience. Due to differences in the sample structure, these results can be estimated only as indicative. Again, this discrepancy in answers given by the Polish respondents can be interpreted as result of their specific professional activities. The analysis of their answers by the criterion of the specific legal profession they perform clearly indicates that the vast majority of Polish civil servants and notaries need speaking skills in English for holding telephone conversations (73\% of civil servants and $80 \%$ of notaries) and more than 
$50 \%$ of respondents from both groups need knowledge of English to express opinions.

The list of preferences in listening skill tasks also differs for the Polish respondents, as they believe that understanding telephone conversation is of utmost importance, which logically corresponds with their answers related to speaking skill objectives. All other nationalities chose the category "listening for detail" as the top one, followed by listening to public statements, before mentioning telephone conversation as such.

There is a consensus among all groups that understanding authentic materials, understanding a specific item of information and the expansion of vocabulary gleaned from authentic materials, is what a lawyer with a good command of English should strive to master where reading skills are concerned, which is confirmed by the Chi-square test $(\mathrm{p}>0.05)$.

The course content part of the questionnaire returned the most varied choices $(\mathrm{p}<0.05)$, which will come as no surprise, because it reflects not only the participants' preferences but also their professional context, therefore the areas of law that should feature in a Legal English syllabus cover all types of law. A more detailed analysis reveals that European law, commercial law and the law of contract are all highly ranked on the list of importance in all four countries, which obviously reflects current internationalization trends in political, legal and economic spheres. All respondents also thought that grammar should be a part of the syllabus but with most of them agreeing that only the essentials should be repeated. The sole exception here was the opinion of German respondents, who thought that grammar should be revised thoroughly (59\%). However, this correlates with the age of the respondents, as the German sample comprised of respondents mostly over the age of 50, who probably have not been learning or repeating grammar rules for a long period of time and at the time when grammar was considered very important. Not surprisingly, lawyers who make their living using words, rank acquiring professional vocabulary as the most important (ranging from $86 \%$ to $94 \%$ across national research groups) and believe it should be taught and learnt by means of different methods and strategies.

Referring to the opening statement in the discussion, it can be stated that the data obtained in this research indicate that 
practising lawyers from the four countries do need Legal English in their everyday working life, and if they do master the language, it gives them a considerable advantage over their competitors within the legal profession.

\section{Limitations of the research}

Due to specific research conditions and the methodology used, our study is not aimed at giving precise statistical data representative for Europe as a whole but at indicating the needs of lawyers performing their jobs in the four referenced EU member states. The conclusions drawn from the comparison of the results can though be of practical didactic value. Although the countries participating in the research differ in their population number and their historical legal development, they are connected by similar legal traditions as well as by the fact that considerable changes have been introduced in their legal systems following their accession to the European Union. In that context, the findings of this research can be a relevant contribution in the sphere of LSP theory and practice and can be used as a relevant background in designing teaching and testing materials in the field of Legal English, if not in a broader European context, then at least in the four countries included in this research.

There have been obvious discrepancies in the sample structure between the four countries related to the age and the professional fields of respondents, which prevented the authors from drawing general conclusions applicable to all the four participating countries. On the other hand, differences in age and in specific legal profession of respondents in those four countries lead to the conclusion that the age of the respondents and their specific professional tasks represent significant statistical variables in determining their needs, indicating that the age and specific legal field in which they practice are strongly correlated with linguistic needs within the framework Legal English. 


\section{Conclusions}

In this study, we have sought to describe the language needs of lawyers practicing in four European countries, and see if there are any similarities that could be taken into consideration when preparing teaching materials, planning the syllabus or assessing the level of Legal English. It became apparent that Legal English is needed by law professionals in most contexts. The results of the study also highlighted what areas should be given particular attention when developing skills in Legal English, namely in public speaking, vocabulary acquisition, legal writing, and telephonic communication.

The implications of this study are that the attention of materials writers, syllabus designers and any other professionals involved in teaching and testing Legal English should be focused on the above-described categories. Discrepancies in the opinions of the respondents coming from different countries should be taken into consideration in syllabus planning and development of teaching materials in each country. The results obtained also indicate that the age of respondents and their professional tasks within a specific legal field should be taken into consideration as the variables determining their specific needs in Legal English. In spite of the limitations of this study, its results can be indicative and serve as a reliable foundation for European countries of similar legal and political background in developing their curricula, teaching materials and corresponding test formats in Legal English that would be internationally applicable.

\section{Acknowledgements}

The authors would like to thank Carol Hogg (Osnabrück University of Applied Sciences, Germany), Štěpánka Bilová, Hana Kallus and Radmila Doupovcová (Masaryk University in Brno, Czech Republic) for their support and assistance in conducting the needs analysis, and Martina Mikrut (University of Osijek, Croatia) for help with the Chisquare test. 
Halina SIEROCKA et al.: Addressing the Needs...

\section{References}

Akbari, Zahra. 2011. Vocabulary comprehension and learning in an ESP context: Strategy use and knowledge sources. The Asian ESP Journal 7(2): 5-27.

Bacha, Nahla Nola and Rima Bahous. 2008. Contrasting views of business students' writing needs in an EFL environment. English for Specific Purposes 27: 74-93.

Basturkmen, Helen. 2006. Ideas and Options in English for Specific Purposes. New York: Routledge.

Benesch, Sarah. 1996. Needs Analysis and Curriculum Development in EAP: An example of a critical approach. Teaching English to Speakers of Other Languages Quarterly 30(4): 732-738.

Chovancová, Barbora. 2013. Legal Minds Think Alike: Legal English Syllabus Design and the Perceived Language Needs of Present and Former Students of Law. ACC Journal 19(3): 54-60.

Chovancová, Barbora. 2014. Needs analysis and ESP course design: Self-perception of language needs among pre-service students. Studies in Logic, Grammar and Rhetoric 38(51): 43-57.

Cowling, Jeremy David. 2007. Needs analysis: Planning a syllabus for a series of intensive workplace courses at a leading Japanese company. English for Specific Purposes 26: 426442.

Deutch, Yocheved. 2003. Needs analysis for academic Legal English courses in Israel: a model of setting priorities. Journal of English for Academic Purposes 2: 125-146.

Dudley-Evans, Tony and Maggie Jo St John. 1998. Developments in English for Specific Purposes Cambridge: Cambridge University Press.

Hutchinson Tony and Alan Waters. 1987. English for Specific Purposes: A Learning-centred Approach. Cambridge: Cambridge University Press.

Hyland, Ken. 2009. Specific purpose programs. In Michael H. Long and Catherine J. Doughty (eds.): The Handbook of Language Teaching, 201-217. Singapore: Wiley-Blackwell.

Jeong, Cheol-Ja. 2005. Learner Needs Analysis for T\&I Program Reform. Meta: Translator Journal 5(4).

Jordan, R.R. 1997. English for Academic Purposes Cambridge: Cambridge University Press. 
Kassim, Hafizoah and Fatimah Ali. 2010. English communicative events and skills needed at the workplace: Feedback from the industry. English for Specific Purposes 29: 168-182.

Lockwood, Jane. 2012. Developing an English for specific purpose curriculum for Asian call centres: How theory can inform practice. English for Specific Purposes 31: 14-24.

Oxford Dictionaries https://en.oxforddictionaries.com. (Accessed 13 September 2017).

Robinson, Pauline C. 1991. ESP Today: A Practitioner's Guide. Hemel Hempstead: Prentice Hall International.

Sierocka, Halina. 2014. Curriculum Development for Legal English Programs. Newcastle upon Tyne: Cambridge Scholars Publishing.

Songhori, Mehdi Haseli. 2008. Introduction to Needs Analysis. English for Specific Purposes World 4: 1-25.

Spratt, Mary. 1999. How good are we at knowing what learners like. System 27: 141-155.

Swales, John M. 1990. Genre Analysis. Cambridge: Cambridge University Press.

Tsao, Chia-hsiu. 2011. English for Specific Purposes in the ELT context. A Survey of Student and Faculty Perceptions. The Asian ESP Journal 7: 126-149.

West, Richard. 1994. Needs analysis in language teaching. Language Teaching 27(1): 1-19.

Wozniak, Séverine. 2010. Language needs analysis from a perspective of international professional mobility: The case of French mountain guides. English for Specific Purposes 29: 243-252. 


\section{APPENDIX}

\section{QUESTIONNAIRE}

This questionnaire was prepared by Dr Halina Sierocka [Białystok Legal English Centre (BLEC), Faculty of Law, University of Białystok, Poland] to specify the most important objectives and to design the content of Legal English courses.

\section{RESPONDENT'S PERSONAL INFORMATION}

\section{Occupation}
a) judge
b) attorney
c) legal advisor / solicitor
d) notary
e) prosecutor
f) bailiff
g) intern (what type of internship?)
h) other

2. Age
a) $23-35$
b) $\quad 36-50$
c) $51-65$
d) over 65

3. Legal English ... (more than one answer can be given):
a) is necessary in my studies
b) is necessary in my work
c) is necessary to improve my skills and qualifications
d) is not necessary in my work
e) would raise my (or my law firm's) value and give an advantage on the labour market
f) other 
I. What would you like to achieve during the Legal English course? Please mark max. TWO most important general objectives of Legal English course.

\begin{tabular}{|l|l|l|}
\hline a) & $\begin{array}{l}\text { I would like to develop the skills necessary to communicate } \\
\text { with other people in my profession }\end{array}$ & \\
\hline b) & $\begin{array}{l}\text { I would like to be able to participate in conversation related } \\
\text { to everyday situations }\end{array}$ & \\
\hline c) & $\begin{array}{l}\text { I would like to be able to establish and maintain } \\
\text { relationships through exchange of information }\end{array}$ & \\
\hline d) $\quad$ I would like to be able to engage in free conversation & \\
\hline e) $\quad$ I would like to be able to maintain correspondence & \\
\hline f) & other: & \\
\hline g) it is difficult to say & \\
\hline
\end{tabular}

II. Which specific objectives within the skills given below are the most important to you?

Please mark the top THREE in the field of WRITING:

\begin{tabular}{|l|l|}
\hline a) formal correspondence & \\
\hline b) informal, private correspondence & \\
\hline c) pleadings / statements of case & \\
\hline d) application letters, CVs, invitations & \\
\hline e) application forms and questionnaires & \\
\hline f) reports, proceedings, notices, memos etc. & \\
\hline g) other: & \\
\hline h) it is difficult to say & \\
\hline
\end{tabular}

Please mark the top THREE in the field of SPEAKING:

\begin{tabular}{|c|c|}
\hline a) & negotiation \\
\hline b) & holding telephone conversations \\
\hline c) & $\begin{array}{l}\text { solving problems in particular situations (e.g. at the post } \\
\text { office, in a restaurant etc.) }\end{array}$ \\
\hline
\end{tabular}


Halina SIEROCKA et al.: Addressing the Needs...

\begin{tabular}{|ll|l|}
\hline d) & giving opinions - agreeing and disagreeing & \\
\hline e) & $\begin{array}{l}\text { discussing topics of interests (e.g. family, hobbies, } \\
\text { travelling etc.) }\end{array}$ & \\
\hline f) & $\begin{array}{l}\text { public speaking (e.g. lectures, commercial presentations, } \\
\text { public speeches etc.) }\end{array}$ & \\
\hline g) other: & \\
\hline h) it is difficult to say & \\
\hline
\end{tabular}

Please mark the top THREE in the field of LISTENING:

\begin{tabular}{|c|c|}
\hline a) & understanding telephone conversations \\
\hline b) & understanding TV or radio news \\
\hline c) & $\begin{array}{l}\text { obtaining necessary information in different situations (e.g. } \\
\text { at the hotel, at the railway station etc.) }\end{array}$ \\
\hline d) & understanding announcements and advertisements \\
\hline e) & listening for details \\
\hline f) & $\begin{array}{l}\text { listening to public statements (e.g. information, instructions } \\
\text { and warnings etc.) }\end{array}$ \\
\hline g) & other: \\
\hline h) & it is difficult to say \\
\hline
\end{tabular}

Please mark the top THREE in the field of READING

\begin{tabular}{|c|c|}
\hline a) & $\begin{array}{l}\text { understanding authentic materials (e.g. reading for gist, } \\
\text { details, etc.) }\end{array}$ \\
\hline b) & searching for and understanding specific information \\
\hline c) & $\begin{array}{l}\text { improving and revising vocabulary on the basis of authentic } \\
\text { materials }\end{array}$ \\
\hline d) & understanding announcements and commercials \\
\hline e) & reading for gist \\
\hline f) & reading and following instructions \\
\hline g) & reading for pleasure \\
\hline h) & other \\
\hline i) & it is difficult to say \\
\hline
\end{tabular}


III. Which particular discipline of law is the most useful to you? Mark a maximum of FOUR disciplines, please.

\begin{tabular}{|l|l|}
\hline a) general features of the English legal system & \\
\hline b) sources of law (e.g. Constitutional law) & \\
\hline c) commercial law & \\
\hline d) criminal law & \\
\hline e) European law & \\
\hline f) administrative law & \\
\hline g) labour law & \\
\hline h) international law & \\
\hline i) financial law & \\
\hline j) civil law (family law, property law, intellectual property & \\
\hline k) contracts & \\
\hline l) tax law & \\
\hline m) other: & \\
\hline n) it is difficult to say & \\
\hline
\end{tabular}

IV. What is the role of grammar in such a course? Mark the appropriate answer, please.

a) grammar should be revised thoroughly

b) only essential grammatical structures should be discussed

c) such a course should not cover grammar

V. Which skill/ skills is/are the value to you in learning a foreign language? (more than one answer can be given)
a) listening
b) writing
c) reading
d) speaking
e) other 
Halina SIEROCKA et al.: Addressing the Needs...

VI. Which is the most important element of Legal English learning? Mark the appropriate answer, please.
a) grammar
b) vocabulary
c) pronunciation
d) other

VII. What is the most helpful to you in the process of learning a foreign language learning (including Legal English)? Mark a maximum of TWO answers, please.
a) books, magazines and newspapers
b) the media (TV, radio, the Internet)
c) games \& puzzles
d) working with a native speaker
e) the use of modern technology
f) working as a lawyer in foreign language environment
g) other

VIII. Any suggestions and / or comments?

Thank you for your time in assisting our research. 